\title{
Effect of Methods of Planting and Planting Geometry on Growth and Yield of Pigeonpea under Rainfed Condition
}

\author{
S. B. Kalaghatagi, Geeta Kalaghatagi*, D. N. Kambrekar and A. K. Guggari \\ Department of Agronomy, College of Agriculture, Vijayapur, University of Agricultural \\ Sciences, Dharwad, Karnataka, India \\ *Corresponding author
}

\section{Keywords}

Methods of planting, Planting geometry, Growth, Yield, Pigeonpea, Rainfed and Net returns

\section{Article Info}

\section{Accepted:}

12 June 2021

Available Online:

10 July 2021

\section{A B S T R A C T}

A field experiment was conducted for four consecutive years during Kharif season of 2009, 2010, 2011 and 2012 to access the suitable methods (dry sowing, transplanting of 25 days aged seedlings and farmers practice) of planting at varied planting geometries $(120 \mathrm{x}$ $90 \mathrm{~cm}$ and $90 \times 20 \mathrm{~cm}$ ) in medium vertisols, under rainfed conditions at Regional Agricultural Research Station Vijayapur. The results revealed that significantly higher grain yield (1805 kg ha ${ }^{-1}$ ) of Pigeonpea was recorded with dry sowing (T1) at $120 \times 90 \mathrm{~cm}$ on June first week and which was found to be at par with the raising of seedlings (T4) on first June in poly bags and transplanting at $120 \mathrm{x} 90 \mathrm{~cm}$ after receipt of good rainfall (1736 $\left.\mathrm{kg} \mathrm{ha}^{-1}\right)$. Significantly lowest gain yield $\left(1372 \mathrm{~kg} \mathrm{ha}^{-1}\right)$ was noticed in recommended practice i.e., sowing after receipt of good rainfall at $90 \times 20 \mathrm{~cm}$ on flat bed (farmers practice). The rainfall received during first week of June 2009, 2010, 2011 was more favorable for advancing crop growth and development when pigeonpea was sown in dry method compared with farmers practice i.e., crop sown after receipt of good rainfall. The extent of yield increase with dry sown method (T1) was $3.82 \%$ and $23.99 \%$ over transplanting of 25 days aged seedlings at 120 x $90 \mathrm{~cm}$ (T4) and recommended practice i.e., crop sown after receipt of good rainfall at $90 \times 20 \mathrm{~cm}$ on flat bed method (T5), respectively. Number of pods plant $^{-1}$ were significantly higher in 120 x $90 \mathrm{~cm}$ with transplanting method (635 plant $\left.^{-1}\right)$ and was at par with that of dry sown method (581 plant $\left.{ }^{1}\right)$ compared to recommended practice i.e., sowing at $90 \times 20 \mathrm{~cm}^{2}\left(196\right.$ plant $\left.^{-1}\right)$. The gross ( $64426 \mathrm{ha}^{-1}$ ) and net returns ( $46960 \mathrm{ha}^{-1}$ ) were significantly higher in dry sowing at $120 \mathrm{x}$ $90 \mathrm{~cm}$ on June first week. The next best treatment was transplanting (T4) of 25 days old seedlings at $120 \times 90 \mathrm{~cm}$ after receipt of good rainfall when compared to rest of the treatments. The farmers practice $(90 \times 20 \mathrm{~cm})$ recorded significantly lowest gross return ( $\left.45862 \mathrm{ha}^{-1}\right)$ and net returns ( $\left.32536 \mathrm{ha}^{-1}\right)$. Significantly higher BC ratio of 3.84 was recorded in dry sown $(120 \times 90 \mathrm{~cm})$ crop followed by sowing after receipt of good rainfall at $120 \times 90 \mathrm{~cm}$ while the transplanted treatment recorded lower BC ratio of 2.89 , though transplanting of 25 days aged seedlings recorded favorable parameters like number of pods plant $^{-1}$, number of branches plant ${ }^{-1}$ and dropped leaf litter per square meter area but the cost of cultivation involved in raising of seedlings in poly bags and transplanting to the main field required higher number of labour per unit area when compared with dry sown method. 


\section{Introduction}

Pigeonpea (Cajanus cajan L.) is tropical pulse crops predominantly grown during the Kharif season both as a sole and intercrop under wide range of agro-ecological situations. The growing period varies depending on cultivar and latitude. The crop gaining popularity to the fact that, it possesses valuable properties as restorative of nitrogen to the soil and adds lot of organic matter to the soil and thus, pigeonpea finds a promising place in crop rotation and crop mixtures. The deep rooting system helps in extracting the nutrients and moisture from deeper soil layers, thus making it suitable for rainfed conditions. Pigeonpea is also one of the major grain legume crop cultivated in the northern dry zone of Karnataka i.e., zone III next to zone II. The yield of pigeonpea is limited by a number of factors such as agronomic, pathogenic, entomological, genetic and their interaction with environment. Among different agronomic practices, date of sowing and choice of suitable geometry/method of planting for a particular genotype are important factors, which are limiting the yields. Long duration pigeonpea can adjust to a wide range of population. The major area under pigeonpea in India is lying between 140 S \& 280 N latitudes; which occupies an area of about 3.90 mha producing $3.38 \mathrm{mt}$. with an average productivity of $871 \mathrm{~kg} \mathrm{ha}^{-1}$ (Anon., 2014). India has virtual monopoly in pigeonpea production by occupying 90 per cent of world's total production in India it is mainly grown in Maharastra, Uttarpradesh, Madhya Pradesh, Gujarath, Andra Pradesh, Karnataka and Tamil Nadu. These states constitute 90 per cent of the area and production of pigeonpea. It is the most important pulse crop of the Karnatak having an area of 8.91 lakh ha, with a production of 52.9 lakh tones and productivity is $625 \mathrm{~kg} \mathrm{ha}^{-1}$ (Anon., 2014). In dry farming areas of Northern dry zone of Karnataka the rainfall is not only scanty, but also erratic and ill distributed. Thus soil moisture becomes the most limiting factor in production of pigeonpea. In order to overcome delayed sowing due to late onset of monsoon, dry sowing on first week of June and transplanting of pigeonpea seedlings are the alternative agronomic options to the farmers. Transplanting techniques involves raising of seedlings in the polythene bags in the nursery for a period of 25 days and then transplanting these seedling in the main field, immediately after receipt of good rainfall. Dry sowing is one of the important noncash input to utilize the early rains effectively and protecting the crop from pest and disease incidence.

\section{Materials and Methods}

A field experiment was conducted at the regional Agricultural Research Station, Vijayapur during Kharif seasons of 2009, 2010, 2011 and 2012 to evaluate the performance of the planting methods (transplanting and dry sowing) and planting geometry of pigeonpea variety BSMR-736. There were five treatments viz., T1- Dry sowing at $120 \times 90 \mathrm{~cm}$ on June first week, T2Sowing after receipt of good rainfall at $120 \mathrm{x}$ $90 \mathrm{~cm}$ and opening ridges and furrows, T3Sowing after receipt of good rain fall at $120 \mathrm{x}$ $90 \mathrm{~cm}, \mathrm{~T} 4-$ Raising of seedlings on June first in poly bags \& transplanting at 120 x $90 \mathrm{~cm}$ after receipt of good rain fall and T5Recommended practice (Sowing after receipt of good rain fall at $90 \times 20 \mathrm{~cm}$ at flat bed with recommended package of practices. The treatments were laid out in randomized block design with five replications. The soils of the experimental site belong to vertisols (medium deep black soils). The experimental site was situated at a latitude of $1604^{\prime} 9^{\prime} \mathrm{N}$ and longitude of 750 4' $\mathrm{E}$ and at an altitude of $593.8 \mathrm{~m}$ above mean seal level. Composite soil samples from $0-30 \mathrm{~cm}$ depth were collected from the site before laying out the 
experiment and analyzed for various physical and chemical properties. The soil was having low available nitrogen (104 $\left.\mathrm{kg} \mathrm{ha}^{-1}\right)$, medium in available phosphorus (22.48 $\mathrm{kg} \mathrm{ha}^{-1}$ ) and high in available potassium (357.2 $\mathrm{kg} \mathrm{ha}^{-1}$ ) content. The $\mathrm{pH}$ of the soil was neutral in reaction ( $\mathrm{pH}=7.69)$ having $\mathrm{EC}$ of $0.54 \mathrm{dSm}-1$ with low organic carbon $(0.41 \%)$ content. The recommended dose of fertilizer for pigeonpea $\left(25: 50 \mathrm{~N} ;\right.$ P2O5 $\left.\mathrm{kg} \mathrm{ha}^{-1}\right)$ along with recommended dose of $\mathrm{ZnSo} 4\left(15 \mathrm{~kg} \mathrm{ha}^{-1}\right)$ was applied as basal dose at the time of sowing in the form of urea and DAP. The fertilizer mixture was applied $5 \mathrm{~cm}$ deep and $5 \mathrm{~cm}$ away from the seed line and mixed thoroughly in the soil. Two to three bold and healthy seeds of pigeonpea (BSMR-736 variety) were sown on first week of June as dry sowing during every year. Simultaneously seeds were sown in polythene bags ( 8 " x 5") having $3 / 4$ th of soil and $20 \mathrm{~g}$ of vermicompost. The polythene bags were watered regularly only one seedling per bag was maintained by thinning excess seedlings. Twenty five days aged seedlings were transplanted to main field on the day of receipt of good rains and also 2-3 seeds were dibbled up to 4 to $5 \mathrm{~cm}$ depth at $90 \times 20 \mathrm{~cm}$ spacing as farmers practice. All crop management practices were followed as per recommended package of practices of the zone. Observations on yield and yield components like number of seeds $\operatorname{pod}^{-1}$, pod weight plant $^{-1}(\mathrm{~g})$, seed weight plant $\left.{ }^{-1} \mathrm{~g}\right), 100$ seed weight (g), seed yield (qha-1) and stalk yield (qha-1) were recorded. At the time of harvest, the leaf litter in each plot was collected from one square meter area, which was weighed and the litter yield per hectare was worked out. The net plot grain yield was converted to grain yield in terms of $\mathrm{kg}$ per ha. Net returns was calculated by deducting cost of cultivation from gross returns, while BC ratio were worked out as a ratio of gross returns to cost of cultivation. The mean annual rainfall of the past 31 years (1981-2012) was $602.00 \mathrm{~mm}$ received in 40 rainy days. The rainfall received during the cropping period during the year 2009, 2010, $2011 \& 2012$ was $1196.30,825.10,564.30$ \& $525.50 \mathrm{~mm}$, respectively (Table 4).

\section{Results and Discussion}

In the present study, the four years pooled data revealed that significantly higher grain yield $\left(1805 \mathrm{~kg} \mathrm{ha}^{-1}\right)$ of pigeonpea was recorded with dry sowing (T1) at $120 \times 90 \mathrm{~cm}$ on June first week which was on par with the raising of seedlings (T4) on first June in poly bags and transplanting at $120 \times 90 \mathrm{~cm}$ after receipt of good rainfall (1736 $\left.\mathrm{kg} \mathrm{ha}^{-1}\right)$. The significantly lowest gain yield (1372 $\left.\mathrm{kg} \mathrm{ha}^{-1}\right)$ was noticed in recommended practice i.e., sowing after receipt of good rainfall at $90 \times 20 \mathrm{~cm}$ flat bed sown treatment (farmers practice). Since method of planting is a non-monetary input, has a considerable influence on growth and yield of a crop. It ensures complete harmony between vegetative and reproductive phases on one hand and climatic rhythm on the other hand.

The rainfall received (Table 4) during first week of June 2009, 2010, 2011 was more favorable for advancing crop growth and development when pigeonpea was sown in dry method when compared with farmers practice i.e., crop sown after receipt of good rainfall. Sowing time determines the time available for vegetative growth before flowering and reproductive parts after flowering which is mainly influenced by photoperiod. The raising of seedlings in poly bags on June first week and transplanting at $120 \times 90 \mathrm{~cm}$ after receipt of good rainfall requires time for establishment in the main field while dry sown treatment had advantage of utilization of early rains effectively. The normal rain fall of 31 years revealed that the rainfall and number of rainy days were favorable for germination of dry sown crop during first week of June (Table 4), the same favorable rainfall trend 
was noticed in 3 years out of 4 years experimentation. The extent of yield increase with dry sown method was 3.82 and $23.99 \%$ over transplanting of 25 days aged seedlings at $120 \times 90 \mathrm{~cm}$ (T4) and recommended practice i.e., crop sown after receipt of good rainfall at 90 x $20 \mathrm{~cm}$ flat bed method (T5), respectively.

Significantly higher grain yield in dry sown treatment might be due to higher growth and yield attributing characters viz., plant height $(200 \mathrm{~cm})$, and grain yield plant-1 (270 g) compared to rest of the methods. Due to availability of higher growing degree-days (GDD), the crop sown during June first week was able to get sufficient sunlight and enabling the crop to absorb sufficient amount of heat units resulting in extended growth period. Similar results were obtained by Shinde and Shinde (1991) who reported sharp decrease in grain yield of redgram with delay in sowing beyond 7th June. Further, Sinha et al., (1989), Padhi (1995) and Patel et al., (1997) reported that sowing on 1st June gave the highest yield and delayed sowings reduced the grain yield significantly. Similarly, Patel et al., (2000) stated that early sown crop on 30th June produced higher grain yield than later sowing dates. Hari Ram et al., (2011) concluded that May 15th sown crop gave $10.3 \%$ higher grain yield than June 1st and $35 \%$ higher than June 15th sown crop.

Grain yield can be expressed by different planting methods and the single plant yield. The present investigation recorded significantly higher grain yield per plant (270 $\mathrm{g}$ ) in dry sown method and it is mainly due to efficient utilization of natural resources. Pigeonpea is no exception because owing to its branching habit and deep root system, it can also adapt to a relatively wider range of plant geometry, the results revealed significantly higher yield in wider spacing of $120 \times 90 \mathrm{~cm}$ irrespective of planting methods. The closer plant geometry of $90 \times 20 \mathrm{~cm}$ (farmers practice) recorded lowest grain yield (1372 kg ha-1), number of pods (196 plant ${ }^{-1}$ ), number of branches (2.8 plant-1) and plant height $(189 \mathrm{~cm})$ compared with wider geometry (Table 2).

Number of pods plant-1 is an important yield contributing trait and were significantly higher in $120 \mathrm{~cm}$ x $90 \mathrm{~cm}$ with transplanting method (635 plant-1) and was on par with dry sown method (581 plant-1) compared to recommended practice i.e., sowing at $90 \times 20$ cm (196 plant- 1).The higher grain yield in $120 \times 90 \mathrm{~cm}$ planting geometry was also attributed to higher growth and yield parameters like plant height and number of branches (Table 1) and such similar results were obtained by Parameswari et al., (2003).

Potdar et al., (2010) also concluded that better performance of individual plants in wider row spacing might be due to better availability of growth resources like water, nutrients, space, better cultural practices coupled with effective weed control. Salakinkoppa and Patil (2010) stated that higher values of growth and yield components obtained in wider row spacing on individual plant basis may be due to improved rate of photosynthesis, dry matter accumulation and its translocation to reproductive parts resulting in higher grain yield plant-1. The present results were also in corroborating with the results of Narasareddy and Nivedeta (1989), Malik (2009), Bhanu Kumar et al., (2011) and Mallikarjun et al., (2014). The better growth parameters (Table 1) in crop sown during June 1st week with planting geometry of 120 x $20 \mathrm{~cm}$ were mainly due to optimum time of sowing and better utilization of available natural resources like solar radiation, soil moisture, space and nutrients by the plants as a consequence of better balance between vegetative and reproductive phase and sufficient time available for setting of pods and giving higher grain yield. 
Table.1 Growth components and dropped leaves per sq.m.(g) as influenced by different method of planting and planting geometry under rainferd condition

\begin{tabular}{|c|c|c|c|c|c|c|c|c|c|c|c|c|c|c|c|c|}
\hline \multirow{2}{*}{$\begin{array}{l}\text { SI. } \\
\text { No. }\end{array}$} & \multirow[t]{2}{*}{ Treatments } & \multicolumn{5}{|c|}{ Plant ht. (cm) } & \multicolumn{5}{|c|}{ No. of branches per plant } & \multicolumn{5}{|c|}{ Dropped leaves per sq.m. (g) } \\
\hline & & 2009 & 2010 & 2011 & 2012 & Pooled & 2009 & 2010 & 2011 & 2012 & Pooled & 2009 & 2010 & 2011 & 2012 & Pooled \\
\hline 2. & $\mathrm{~T} 2$ & 202 & 193 & 193 & 190 & 195 & 4.44 & 3.74 & 3.72 & 3.6 & 3.92 & 653 & 700 & 692 & 665 & 677 \\
\hline 4. & $\mathrm{~T} 4$ & 201 & 192 & 194 & 192 & 195 & 4.56 & 3.98 & 4.00 & 3.6 & 4.02 & 545 & 635 & 604 & 563 & 587 \\
\hline 5. & T5 & 205 & 189 & 191 & 189 & 193 & 2.92 & 2.60 & 3.00 & 2.8 & 2.83 & 1,029 & 1079 & 1122 & 1060 & 1073 \\
\hline & SEm \pm & 4.37 & 4.39 & 4.29 & 2.96 & 2.02 & 0.26 & 0.24 & 0.28 & 0.27 & 0.13 & 22.75 & 22.42 & 18.96 & 39.61 & 13.58 \\
\hline
\end{tabular}

T1 - Dry sowing at $120 \times 90 \mathrm{~cm}$ on June first

T2 - Sowing after receipt of good rainfall at 120 X $90 \mathrm{~cm}$ and opening ridges and furrows T3 - Sowing after receipt of good rainfall at $120 \mathrm{x} 90$ $\mathrm{cm}$

T4 - Raising of seedlings on June first in poly bags and transplanting at 120 x $90 \mathrm{~cm}$ after receipt of good rainfall T5 - Recommended practice (sowing after receipt of good rainfall at $90 \times 20 \mathrm{~cm}$ at flat bed)

Table.2 Yield and yield components as influenced by different method of planting and planting geometry under rain fed condition

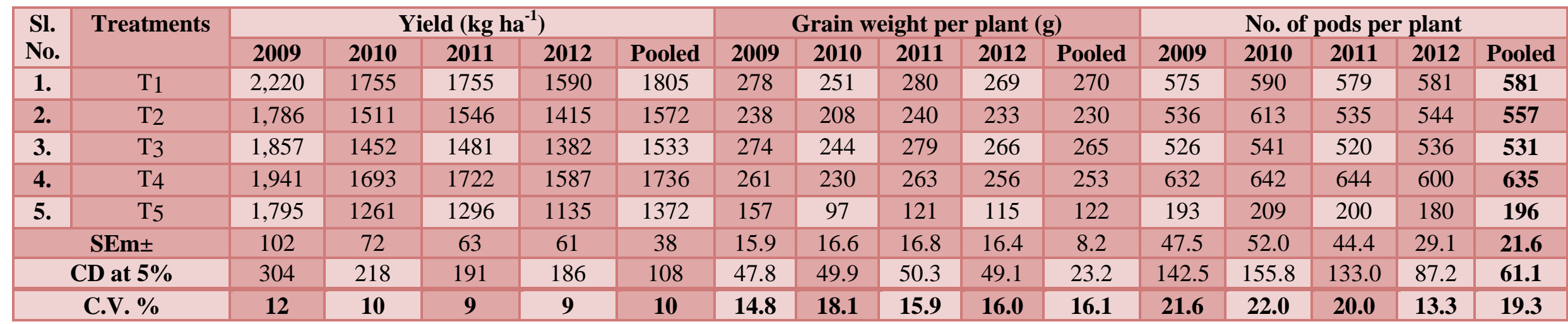


Table.3 Economics of pigeonpea cultivation as influenced by different methods of planting and planting geometry under rainfed condition

\begin{tabular}{|c|c|c|c|c|c|c|c|c|c|c|c|c|c|c|c|c|}
\hline \multirow{2}{*}{$\begin{array}{l}\text { Sl. } \\
\text { No. }\end{array}$} & \multirow[t]{2}{*}{ Treatments } & \multicolumn{5}{|c|}{ Gross return $\left(\mathrm{ha}^{-1}\right)$} & \multicolumn{5}{|c|}{ Net Returns ( ha $\left.^{-1}\right)$} & \multicolumn{5}{|c|}{ BC Ratio } \\
\hline & & 2009 & 2010 & 2011 & 2012 & Pooled & 2009 & 2010 & 2011 & 2012 & Pooled & 2009 & 2010 & 2011 & 2012 & Pooled \\
\hline 2 & $\mathrm{~T} 2$ & 58945 & 49011 & 48837 & 53971 & 52646 & 43945 & 33931 & 33737 & 38800 & 37603 & 2.93 & 2.25 & 2.23 & 3.59 & 2.92 \\
\hline 4 & $\mathrm{~T} 4$ & 64066 & 54921 & 53394 & 60316 & 58175 & 48516 & 39291 & 37744 & 44738 & 42572 & 3.12 & 2.51 & 2.41 & 3.87 & 2.89 \\
\hline 5 & T5 & 59242 & 40907 & 40182 & 43121 & 45862 & 45942 & 27527 & 26782 & 29894 & 32536 & 3.45 & 2.06 & 2.00 & 3.26 & 2.67 \\
\hline & SEm \pm & 2979 & 2521 & 2184 & 2362 & 1286 & 3014 & 2503 & 2155 & 2748 & 1333 & 0.24 & 0.19 & 0.16 & 0.17 & 0.08 \\
\hline
\end{tabular}


Table.4 Rainfall (mm) behaviour during 2009, 2010, 2011 and 2012

\begin{tabular}{|c|c|c|c|c|c|c|c|c|c|c|c|c|c|c|c|c|c|c|c|c|c|c|c|c|}
\hline \multirow[b]{3}{*}{ Date } & \multicolumn{6}{|c|}{2009} & \multicolumn{6}{|c|}{2010} & \multicolumn{6}{|c|}{2011} & \multicolumn{6}{|c|}{2012} \\
\hline & \multicolumn{2}{|c|}{ June } & \multicolumn{2}{|c|}{ July } & \multicolumn{2}{|c|}{ August } & \multicolumn{2}{|c|}{ June } & \multicolumn{2}{|c|}{ July } & \multicolumn{2}{|c|}{ August } & \multicolumn{2}{|c|}{ June } & \multicolumn{2}{|c|}{ July } & \multicolumn{2}{|c|}{ August } & \multicolumn{2}{|c|}{ June } & \multicolumn{2}{|c|}{ July } & \multicolumn{2}{|c|}{ August } \\
\hline & $\begin{array}{l}\text { Rain } \\
\text { fall }\end{array}$ & $\begin{array}{c}\text { Rai } \\
\text { ny } \\
\text { Da } \\
\text { ys }\end{array}$ & $\begin{array}{l}\text { Rain } \\
\text { fall }\end{array}$ & $\begin{array}{c}\text { Rai } \\
\text { ny } \\
\text { Da } \\
\text { ys }\end{array}$ & $\begin{array}{l}\text { Rain } \\
\text { fall }\end{array}$ & $\begin{array}{c}\text { Rai } \\
\text { ny } \\
\text { Da } \\
\text { ys }\end{array}$ & $\begin{array}{c}\text { Rain } \\
\text { fall }\end{array}$ & $\begin{array}{l}\text { Rai } \\
\text { ny } \\
\text { Da } \\
\text { ys }\end{array}$ & $\begin{array}{l}\text { Rain } \\
\text { fall }\end{array}$ & $\begin{array}{c}\text { Rai } \\
\text { ny } \\
\text { Da } \\
\text { ys }\end{array}$ & $\begin{array}{c}\text { Rain } \\
\text { fall }\end{array}$ & $\begin{array}{l}\text { Rai } \\
\text { ny } \\
\text { Da } \\
\text { ys }\end{array}$ & $\begin{array}{c}\text { Rain } \\
\text { fall }\end{array}$ & $\begin{array}{c}\text { Rai } \\
\text { ny } \\
\text { Da } \\
\text { ys }\end{array}$ & $\begin{array}{l}\text { Rain } \\
\text { fall }\end{array}$ & $\begin{array}{l}\text { Rai } \\
\text { ny } \\
\text { Da } \\
\text { ys }\end{array}$ & $\begin{array}{l}\text { Rain } \\
\text { fall }\end{array}$ & $\begin{array}{l}\text { Rai } \\
\text { ny } \\
\text { Da } \\
\text { ys }\end{array}$ & $\begin{array}{l}\text { Rain } \\
\text { fall }\end{array}$ & $\begin{array}{l}\text { Rai } \\
\text { ny } \\
\text { Da } \\
\text { ys }\end{array}$ & $\begin{array}{c}\text { Rain } \\
\text { fall }\end{array}$ & $\begin{array}{l}\text { Rai } \\
\text { ny } \\
\text { Da } \\
\text { ys }\end{array}$ & $\begin{array}{l}\text { Rain } \\
\text { fall }\end{array}$ & $\begin{array}{c}\text { Rai } \\
\text { ny } \\
\text { Da } \\
\text { ys }\end{array}$ \\
\hline 1 & 0 & 0 & 0 & 0 & 0 & 0 & 0 & 0 & 0 & 0 & 0 & 0 & 0 & 0 & 0 & 0 & 0.2 & 0 & 0 & 0 & 0 & 0 & 0 & 0 \\
\hline 2 & 0 & 0 & 0 & 0 & 0 & 0 & 14.2 & 1 & 0 & 0 & 0.8 & 0 & 3.4 & 1 & 0 & 0 & 0 & 0 & 0 & 0 & 0 & 0 & 0 & 0 \\
\hline 3 & 0 & 0 & 0 & 0 & 0 & 0 & 0 & 0 & 0 & 0 & 0.6 & 0 & 4.4 & 1 & 0 & 0 & 21.6 & 1 & 0 & 0 & 0 & 0 & 2.4 & 0 \\
\hline 4 & 0 & 0 & 0 & 0 & 0 & 0 & 2.2 & 0 & 0 & 0 & 0 & 0 & 7.9 & 1 & 0 & 0 & 0.2 & 0 & 0 & 0 & 0 & 0 & 0.2 & 0 \\
\hline 5 & 0 & 0 & 0 & 0 & 0 & 0 & 0 & 0 & 0 & 0 & 0 & 0 & 2.4 & 1 & 0 & 0 & 0 & 0 & 1 & 0 & 0 & 0 & 0.4 & $\mathbf{0}$ \\
\hline 6 & 0 & 0 & 0 & 0 & 0 & 0 & 0 & 0 & 0.4 & 0 & 0 & 0 & 3.6 & 1 & 4.3 & 1 & 0 & 0 & 0 & 0 & 0 & 0 & 0 & 0 \\
\hline 7 & 13.4 & 1 & 0 & 0 & 0 & 0 & 0 & 0 & 0 & 0 & 0 & 0 & 4 & 1 & 7.8 & 1 & 0 & 0 & 0 & 0 & 0 & 0 & 3.6 & 1 \\
\hline 8 & 0 & 0 & 0 & 0 & 0 & 0 & 0 & 0 & 0.8 & 0 & 0 & 0 & 0 & 0 & 0 & 0 & 7.6 & 1 & 0 & 0 & 0 & 0 & 1.4 & 0 \\
\hline 9 & 0 & 0 & 0 & 0 & 0 & 0 & 0 & 0 & 0 & 0 & 0 & 0 & 0 & 0 & 0 & 0 & 0 & 0 & 0 & 0 & 0 & 0 & 0 & 0 \\
\hline 10 & 0 & 0 & 0.6 & 0 & 0 & 0 & 49.2 & 1 & 0 & 0 & 0 & 0 & 0 & 0 & 3.4 & 1 & 0 & 0 & 0 & 0 & 0 & 0 & 0 & 0 \\
\hline 11 & 0.4 & 0 & 0 & 0 & 0.6 & 0 & 4.2 & 1 & 0 & 0 & 0 & 0 & 1.6 & 0 & 0 & 0 & 0 & 0 & 0 & 0 & 0 & 0 & 1 & 0 \\
\hline 12 & 26.2 & 1 & 6.2 & 1 & 0.2 & 0 & 12.2 & 1 & 0 & 0 & 0.8 & 0 & 0 & 0 & 0 & 0 & 0 & 0 & 0 & 0 & 0 & 0 & 0 & 0 \\
\hline 13 & 0 & 0 & 0 & 0 & 0 & 0 & 23.6 & 1 & 0 & 0 & 22.2 & 1 & 0 & 0 & 0 & 1 & 0 & 0 & 0 & 0 & 0 & 0 & 1.4 & 0 \\
\hline 14 & 0 & 0 & 0 & 0 & 0 & 0 & 2.3 & 0 & 0 & 0 & 34.2 & 1 & 0 & 0 & 7.4 & 1 & 0 & 0 & 0 & 0 & 0 & 0 & 0 & 0 \\
\hline 15 & 56.6 & 0 & 0.4 & 0 & 3.2 & 0 & 0 & 0 & 5.8 & 0 & 0 & 0 & 0 & 0 & 0 & 0 & 0 & 0 & 0 & 0 & 0 & 0 & 0 & 0 \\
\hline 16 & 0 & 0 & 0.9 & 0 & 0.2 & 0 & 0 & 0 & 0 & 0 & 31.6 & 0 & 0 & 0 & 0.6 & 0 & 0 & 0 & 0 & 0 & 0.6 & 0 & 0 & 0 \\
\hline 17 & 0 & 1 & 0.5 & 0 & 21.6 & 1 & 2.8 & 1 & 0 & 0 & 0 & 1 & 0 & 0 & 0 & 0 & 13.2 & 1 & 0 & 0 & 38.2 & 1 & 0 & 0 \\
\hline 18 & 32.4 & 1 & 0 & 0 & 5.2 & 1 & 0 & 0 & 0 & 0 & 5.2 & 1 & 0 & 0 & 0 & 0 & 0 & 0 & 2.6 & 1 & 18.6 & 1 & 0 & 0 \\
\hline 19 & 39.6 & 1 & 0.4 & 0 & 0.2 & 0 & 0 & 0 & 0 & 0 & 0 & 0 & 0 & 0 & 0 & 0 & 2.4 & 0 & 11 & 1 & 0 & 0 & 0 & 0 \\
\hline 20 & 0 & 0 & 0 & 0 & 47.6 & 1 & 6.8 & 1 & 0 & 0 & 0 & 0 & 0 & 0 & 0 & 0 & 0 & 0 & 0 & 0 & 2.2 & 0 & 0 & 0 \\
\hline 21 & 0 & 0 & 0 & 0 & 0 & 0 & 0 & 0 & 0 & 0 & 0 & 0 & 0 & 0 & 0 & 0 & 7.2 & 1 & 0 & 0 & 3.6 & 1 & 0 & 0 \\
\hline 22 & 0 & 0 & 0 & 0 & 2.3 & 0 & 0 & 0 & 1 & 0 & 67.8 & 1 & 0 & 0 & 0 & 0 & 5.4 & 1 & 0 & 0 & 0 & 0 & 0 & 0 \\
\hline 23 & 0 & 0 & 0 & 0 & 38.8 & 1 & 0 & 0 & 1.2 & 0 & 0.2 & 0 & 0 & 0 & 0.2 & 0 & 0 & 0 & 0 & 0 & 0 & 0 & 0 & 0 \\
\hline 24 & 0 & 0 & 0.4 & 0 & 70 & 0 & 27 & 1 & 4 & 0 & 0 & 0 & 0 & 0 & 2.8 & 0 & 0 & 0 & 0 & 0 & 0 & 0 & 0 & $\mathbf{0}$ \\
\hline 25 & 0 & 0 & 0 & 0 & 44 & 0 & 0 & 0 & 0.3 & 0 & 2.4 & 0 & 0 & 0 & 0 & 0 & 33.2 & 1 & 0 & 0 & 0 & 0 & 0 & 0 \\
\hline 26 & 0 & 0 & 0 & 0 & 25.2 & 1 & 0 & 0 & 10.6 & 1 & 19.2 & 1 & 0 & 0 & 0 & 0 & 17.4 & 1 & 0 & 0 & 0 & 0 & 41 & 1 \\
\hline 27 & 0 & 0 & 0 & 0 & 0 & 0 & 0 & 0 & 3.4 & 1 & 1.6 & 0 & 0 & 0 & 4.2 & 0 & 1 & 0 & 8 & 1 & 0 & 0 & 5.6 & 1 \\
\hline 28 & 0 & 0 & 0.2 & 0 & 0 & 0 & 0 & 0 & 2.6 & 0 & 2.6 & 1 & 0 & 0 & 0 & 0 & 4.2 & 1 & 1 & 0 & 0 & 0 & 3 & 1 \\
\hline
\end{tabular}


Int.J.Curr.Microbiol.App.Sci (2021) 10(07): 79-88

\begin{tabular}{|c|c|c|c|c|c|c|c|c|c|c|c|c|c|c|c|c|c|c|c|c|c|c|c|c|}
\hline 29 & 0 & 0 & 5.2 & 1 & 0 & 0 & 0 & 0 & 2.8 & 0 & 10.4 & 1 & 0.2 & 0 & 0 & 0 & 0 & 0 & 1.2 & 0 & 0 & 0 & 0 & 0 \\
\hline 30 & 0 & 0 & 1 & 0 & 0 & 0 & 0 & 0 & 2 & 0 & 0 & 0 & 0 & 0 & 0 & 0 & 0 & 0 & 1.2 & 0 & 0 & 0 & 0 & 0 \\
\hline 31 & 0 & 0 & 0 & 0 & 0 & 0 & 0 & 0 & 0 & 0 & 0 & 0 & 0 & 0 & 0 & 0 & 0 & 0 & 0 & 0 & 0 & 0 & 0 & 0 \\
\hline Total & $\begin{array}{c}168 . \\
6\end{array}$ & 5 & 15.8 & 2 & $\begin{array}{c}259 . \\
1\end{array}$ & 5 & $\begin{array}{c}144 . \\
5\end{array}$ & 8 & 34.9 & 2 & $\begin{array}{c}199 . \\
6\end{array}$ & 8 & 27.5 & 6 & 30.7 & 5 & $\begin{array}{c}113 . \\
6\end{array}$ & 8 & 26 & 3 & 63.2 & 3 & 60 & 4 \\
\hline $\begin{array}{l}\text { Nor } \\
\text { mal } \\
\text { RF }\end{array}$ & 82.8 & 79 & 82.3 & $\begin{array}{c}82 . \\
8\end{array}$ & 79 & $\begin{array}{c}82 . \\
3\end{array}$ & 82.8 & 79 & 82.3 & $\begin{array}{c}82 . \\
8\end{array}$ & 79 & $\begin{array}{c}82 . \\
3\end{array}$ & 82.8 & 79 & 82.3 & $\begin{array}{c}82 . \\
8\end{array}$ & 79 & $\begin{array}{c}82 . \\
3\end{array}$ & 82.8 & 79 & 82.3 & $\begin{array}{c}82 . \\
8\end{array}$ & 79 & $\begin{array}{c}82 . \\
3\end{array}$ \\
\hline $\begin{array}{c}\% \\
\text { Devi } \\
\text { aton }\end{array}$ & $\begin{array}{c}103 . \\
62\end{array}$ & $\begin{array}{c}- \\
93 . \\
67\end{array}$ & $\begin{array}{c}- \\
80.8 \\
0\end{array}$ & $\begin{array}{c}- \\
97 . \\
58\end{array}$ & $\begin{array}{c}227 . \\
97\end{array}$ & $\begin{array}{c}- \\
93 . \\
92\end{array}$ & $\begin{array}{c}74.5 \\
2\end{array}$ & $\begin{array}{c}- \\
89 . \\
87\end{array}$ & $\begin{array}{c}- \\
57.5 \\
9\end{array}$ & $\begin{array}{c}- \\
97 . \\
58\end{array}$ & $\begin{array}{c}152 . \\
66\end{array}$ & $\begin{array}{c}- \\
90 . \\
28\end{array}$ & $\begin{array}{c}- \\
66.7 \\
9\end{array}$ & $\begin{array}{c}- \\
92 . \\
41\end{array}$ & $\begin{array}{c}- \\
62.7 \\
0\end{array}$ & $\begin{array}{c}- \\
93 . \\
96\end{array}$ & $\begin{array}{c}43.8 \\
0\end{array}$ & $\begin{array}{c}- \\
90 . \\
28\end{array}$ & $\begin{array}{c}- \\
68.6 \\
0\end{array}$ & $\begin{array}{c}- \\
96 . \\
20\end{array}$ & $\begin{array}{c}- \\
23.2 \\
1\end{array}$ & $\begin{array}{c}- \\
96 . \\
38\end{array}$ & $\begin{array}{c}- \\
24.0 \\
5\end{array}$ & $\begin{array}{c}- \\
95 . \\
14\end{array}$ \\
\hline
\end{tabular}




\section{Economic Analysis}

The table 3 revealed that the gross ( 64426 ha1) and net returns ( 46960 ha-1) were significantly higher in dry sowing at $120 \times 90$ $\mathrm{cm}$ during June first week.

The next best treatment was transplanting (T4) of 25 days old seedlings at $120 \times 90 \mathrm{~cm}$ after receipt of good rainfall when compared with rest of the treatments.

The farmers practice $(90 \times 20 \mathrm{~cm})$ recorded significantly lowest gross return ( 45862 ha1) and net returns of Rs 32536 ha- 1. Significantly higher BC ratio of 3.84 was recorded in dry sown $(120 \times 90 \mathrm{~cm})$ crop followed by sowing after receipt of good rainfall at $120 \times 90 \mathrm{~cm}$ while the transplanted treatment recorded lower BC ratio of 2.89, though transplanting of 25 days aged seedlings as recorded favorable parameters like number of pods per plant, number of branches per plant and dropped leaf litter per square meter area was favorable but the cost of cultivation involved in raising of seedlings in poly bags and transplanting to the main field required higher number of labour per unit area when compared with dry sown method.

Under rainfed dryland conditions the availability of water is constraint hence dry sowing method is more feasible technology for resource poor farmers.

The next best technology is transplanting technique where ever water is available either through bore well or open wells on the farm.

The dry sowing technology is feasible method for resource poor farmers under rainfed conditions and transplanting technique is advocated wherever irrigation sources are available especially during may and June months to advance the planting date for favorable growth and yield parameters.

\section{References}

Anonymous, (2014). Directorate of economics and statistics, department of agriculture and co- operation, ministry of agriculture, Government of India.

Bhanu Kumar, M., Hulihalli, U. K., Aravind Kumar, B. N. and Meena, M. K. (2011). Effect of fertility and planting geometry on growth and yield of medium duration pigeonpea hybrid ICPH-2671. Res. J. Agric. Sci., 2(3) : 715-718.

Hari Ram, Guriqbal Singh, Sekhon, H.S. and Veena Khanna, (2011). Effect of sowing time on the performance of pigeonpea genotypes, J. of Food Legumes, 24(3): 207-210.

Malik, R. I. J. (2009). Effect of nursery techniques, seedling age and spacing on seed yield and quality in transplanted redgram. M. Sc. (Agri.) Thesis, Univ. Agril. Sci., Dharwad, Karnataka.

Mallikarjun, C., Hulihalli, U. K., Somanagouda, G., Kubsad, V. S. and Kambrekar, D. N. (2014). Performance of hybrid pigeonpea (cv. ICPH-2671) under varied planting methods and planting geometries in Northern dry zone of Karnataka.Karnataka J. Agric. Sci., 27(3): 296-299.

Narsareddy, S. and Nivedita, R. (1989). Pattern of dry matter accumulation, nutrient content and yield response of pigeonpea varieties as influenced by phosphorus levels and spacings. $J$. Res., APAU, 17(4) : 421-423.

Padhi, A. K. (1995). Effect of sowing date and planting geometry on yield of redgram (Cajanus cajan) genotypes, Indian J. Agron. 40(1): 72-76

Patel, N. R., Mehta, A. N. and Shekh, A. M. (1997). Effect of sowing date and row spacing on phenology and yield of two diverse genotypes of pigeonpea 
(Cajanus cajan). Indian J. Agril. Sci., 67(4): 153-156.

Patel, N. R., Mehta, A. N. and Shekh, A. M., 2000, Radiation absorption, growth and yield of pigeonpea cultivars as influenced by sowing dates. Exptal. Agric., 36 (3) : 291-301

Parameswari, K., Vanangamudi, K. and Kavitha, S. (2003). Effect of spacing on seed yield of pigeonpea hybrid CoPH-2. Madras Agric. J., 90(10-12): 691-696.

Potdar, M. P., Chittapur, B. M., Salakinkoppa, S. R., Arjun sharma and Dharmraj, P. S. (2010). Response of transplanted pigeonpea (Cajanus cajana L.) to planting geometry under rainfed conditions of North Eastern dry zone of Karnataka, Nation. Symp. on "Resource Management Approaches towards Livelihood Security, 2-4 December, Bengaluru, Karnataka
Salakinkoppa, S. R. and Patil, H. Y. (2010). Enhancing the productivity of pigeonpea by transplanting technique in command area. National Symposium on "Food Security in Context of changing climate" held at Kanpur during October 30th to November 01st, pp. 113.

Shankaralingappa, B. C. and Hegde, B. R. (1989). Effect of date of sowing and plant population on pigeonpea, Indian J. Agron. 34(1): 99-101.

Shinde, J. B. and Shinde, S. H. (1991). Effect of seeding date on yield of rainy season pigeonpea (Cajanus cajan). Indian J. of Agron., 36(3): 430-431.

Sinha, A. C., Mandal, B. S. and Jana, P. K. (1989). Effect of time of sowing, row spacing and weed control measures on production of pigeonpea. Indian $J$. Agron., 34(3): 285-285.

\section{How to cite this article:}

Kalaghatagi, S. B., Geeta Kalaghatagi, D. N. Kambrekar and Guggari, A. K. 2021. Effect of Methods of Planting and Planting Geometry on Growth and Yield of Pigeonpea under Rainfed Condition. Int.J.Curr.Microbiol.App.Sci. 10(07): 79-88. doi: https://doi.org/10.20546/ijcmas.2021.1007.009 